OPEN ACCESS

Edited by:

Victoria Fernandez,

Polytechnic University of

Madrid, Spain

Reviewed by:

José Lavres Junior,

University of São Paulo, Brazil Elizabeth Van Volkenburgh, University of Washington,

United States

${ }^{*}$ Correspondence:

Xiaokun $\mathrm{LI}$

lixiaokun@mail.hzau.edu.cn

Specialty section:

This article was submitted to Plant Nutrition, a section of the journal Frontiers in Plant Science

Received: 29 October 2019 Accepted: 04 February 2020

Published: 27 February 2020

Citation:

Hou W, Tränkner M, Lu J, Yan J, Huang $S$, Ren T, Cong R and LiX (2020) Diagnosis of Nitrogen Nutrition in Rice Leaves Influenced by Potassium Levels.

Front. Plant Sci. 11:165. doi: $10.3389 /$ fpls.2020.00165

\section{Diagnosis of Nitrogen Nutrition in Rice Leaves Influenced by Potassium Levels}

\author{
Wenfeng Hou ${ }^{1}$, Merle Tränkner ${ }^{2}$, Jianwei Lu ${ }^{1}$, Jinyao Yan ${ }^{1}$, Siyuan Huang ${ }^{1}$, Tao Ren ${ }^{1}$, \\ Rihuan Cong ${ }^{1}$ and Xiaokun $\mathrm{Li}^{1{ }^{*}}$ \\ 1 Key Laboratory of Arable Land Conservation (Middle and Lower Reaches of Yangtze River), Ministry of Agriculture/ \\ Microelement Research Center/College of Resources and Environment, Huazhong Agricultural University, Wuhan, China, \\ 2 Department of Crop Sciences, Institute of Applied Plant Nutrition (IAPN), Georg-August-University Göttingen, Göttingen, \\ Germany
}

Evaluation of nitrogen $(\mathrm{N})$ status by leaf color is a kind of classic nutritional diagnostic method. However, the color of leaves is influenced not only by $\mathrm{N}$, but also by other nutrients such as potassium (K). Two-year field trials with a factorial combination of $\mathrm{N}$ and $K$ were conducted to investigate the effects of different $N$ and $K$ rates on soil plant analysis development (SPAD) readings and leaf $\mathrm{N}, \mathrm{K}$, magnesium (Mg), and chlorophyll concentrations. Visual inspections in leaf greenness revealed darker green leaves with increasing $\mathrm{N}$ rates, while paler green leaves with increasing $\mathrm{K}$ rates. Data showed that SPAD readings, chlorophyll, $\mathrm{N}$ and $\mathrm{Mg}$ concentrations, and the chloroplast area increased significantly with raising $\mathrm{N}$ rates, while declined sharply with the increase in $\mathrm{K}$ rates due to the antagonistic relationships between $\mathrm{K}^{+}$and $\mathrm{NH}_{4}{ }^{+}$as well as $\mathrm{Mg}^{2+}$. It was also probable that the increase in $\mathrm{K}$ promoted the growth of leaves and diluted their $\mathrm{N}$ and $\mathrm{Mg}$ concentrations. The paler leaf appearance resulting from the application of $\mathrm{K}$ may overestimate the actual demand for $\mathrm{N}$ in the diagnosis of rice $\mathrm{N}$ status. The strong antagonistic relationships between $\mathrm{K}^{+}, \mathrm{NH}_{4}{ }^{+}$, and $\mathrm{Mg}^{2+}$ should be considered in rice production and fertilization.

Keywords: chlorophyll, leaf greenness, nitrogen, potassium, SPAD

\section{INTRODUCTION}

Rice (Oryza Sativa L.) is one of the most important crops feeding the world's population (Chapagain and Hoekstra, 2011). Predicted results showed that $70 \%$ more food will be needed by 2050 (Long, 2012). With the increasing population and decreasing arable land, it is of great importance to ensure food safety by improving rice yield per unit area (Jiang et al., 2016). Nitrogen $(\mathrm{N})$ and potassium (K) are two elements that are required in great quantities for rice growth and yield formation (Pettigrew, 2008; Zhu et al., 2008; Oosterhuis et al., 2014). However, there are several problems concerning the application of $\mathrm{N}$ and $\mathrm{K}$ fertilizers in paddy fields.

Farmers usually apply excessive amounts of $\mathrm{N}$ to ensure high grain yields, which greatly depend on $\mathrm{N}$ inputs (Castillejo et al., 2010; Kaufman et al., 2013). Although the supply of N significantly improves grain yield, the low $\mathrm{N}$ use efficiency for the surplus application of $\mathrm{N}$ has been a major 
characteristic of rice production systems (Zhang et al., 2009; Qiao et al., 2012). In addition, the high input of $\mathrm{N}$ has substantial economic and environmental costs and results lodging (Guo et al., 2010; Zhang et al., 2016). In contrast, the importance of $\mathrm{K}$ has sometimes been over looked because the grain yield response to $\mathrm{K}$ is generally lower than that observed for $\mathrm{N}$ (Baligar, 2001). Farmers are also compelled to prioritize $\mathrm{N}$ over $\mathrm{K}$ due to the financial constraints (Hoa et al., 2006; Andrist-Rangel et al., 2007). The removal of crop residues from the field also accelerates the consumption of soil K (Timsina et al., 2013). As a result, low-K availability in paddy soils is a critical factor restricting the increase of grain yield (Zhang et al., 2013; Qiu et al., 2014; Zörb et al., 2014).

Leaves are the principal organs responsible for photosynthesis in vascular plants and contribute more than $90 \%$ of the crop biomass (Makino, 2011; Xiong et al., 2016). The supply of $\mathrm{N}$ could delay leaf senescence, maintaining the photosynthetic activity and rate for a longer period (Luo et al., 2018). Nitrogen plays important roles in leaf photosynthesis and the formation of grain yield, because it is required for the synthesis of numerous cellular components, such as amino acids, proteins, chlorophyll, and nucleic acids (Kusano et al., 2011; Makino, 2011; Pradhan et al., 2014). Approximately, $80 \%$ of leaf $\mathrm{N}$ is allocated to the chloroplasts and approximately $50 \%$ of such $\mathrm{N}$ is in the form of photosynthetic proteins, including those important for the light harvesting process, electron transport, and the enzymatic machinery of carbon metabolism (Xiong et al., 2015). Nitrogen deficiency could significantly decrease the $\mathrm{N}$ concentration, leaf area and chlorophyll concentration, SPAD readings, photosynthesis, and lead to lower biomass (Zhao et al., 2005; Berenguer et al., 2009). Potassium is not a functional or structural component within organic molecules in plants but functions as an inorganic cation incell extension, stomatal movement, osmoregulation, enzyme activation, photosynthesis, protein synthesis, phloem loading, and transport (Pettigrew, 2008; Zörb et al., 2014). Furthermore, K deficiency restricts the diffusion of $\mathrm{CO}_{2}$ through the leaf mesophyll and results in low substrate availability for carbon (C) fixation in chloroplasts (Jákli et al., 2016; Hou et al., 2018). These two factors, the chlorophyll concentration and restricted $\mathrm{CO}_{2}$ diffusion through the mesophyll, may contribute to a reduction in photosynthesis.

Previous studies have shown highly positive correlations between SPAD (Soil Plant Analysis Development) readings and chlorophyll and N concentrations (Singh et al., 2002; Wang et al., 2014; Ata-Ul-Karim et al., 2016). The use of SPAD measurements has been widely applied to monitor rice $\mathrm{N}$ status and to evaluate $\mathrm{N}$ demand of rice at different growth stages for improving grain yield and $\mathrm{N}$ use efficiency (Khurana et al., 2007; Huang et al., 2008). In a field trial we observed that there were obvious differences in leaf greenness between different $\mathrm{K}$ rates at low $\mathrm{N}$ rates, whereas no obvious differences in leaf greenness between different $\mathrm{K}$ rates at high $\mathrm{N}$ rates.

Thereby, in relation to this observation, the objectives of this work were: (i) to investigate the effects of different $\mathrm{N}$ and $\mathrm{K}$ rates on leaf greenness and (ii) to evaluate the effects of different levels of leaf greenness on grain yield.

\section{MATERIALS AND METHODS}

\section{Experimental Site and Experimental Design}

The experiments were conducted in Wuxue County $\left(30^{\circ} 06^{\prime} 46^{\prime \prime} \mathrm{N}\right.$, $\left.115^{\circ} 36^{\prime} 9^{\prime \prime} \mathrm{E}\right)$, Hubei province, central China in 2016 and 2017. Figure 1 shows the temperature and precipitation within the rice growing seasons of 2016 and 2017. The daily mean temperature was $24.3^{\circ} \mathrm{C}$ and $24.9^{\circ} \mathrm{C}$, the daily mean precipitation was 11.3 $\mathrm{mm}$ and $6.7 \mathrm{~mm}$ respectively. Plants were grown in a sandy loam field with $16.4 \%$ clay, $36.8 \%$ silt, $46.8 \%$ sand, a $\mathrm{pH}$ of 5.8 (soil: water $=1: 2.5$ ), organic matter concentration of $32.1 \mathrm{~g} \mathrm{~kg}^{-1}$, total $\mathrm{N}$ of $1.8 \mathrm{~g} \mathrm{~kg}^{-1}$, Olsen-P of $13.4 \mathrm{mg} \mathrm{kg}^{-1}$, readily available $\mathrm{K}$ of $44.5 \mathrm{mg} \mathrm{kg}^{-1}$, and slowly available $\mathrm{K}$ of $302.5 \mathrm{mg} \mathrm{kg}^{-1}$.

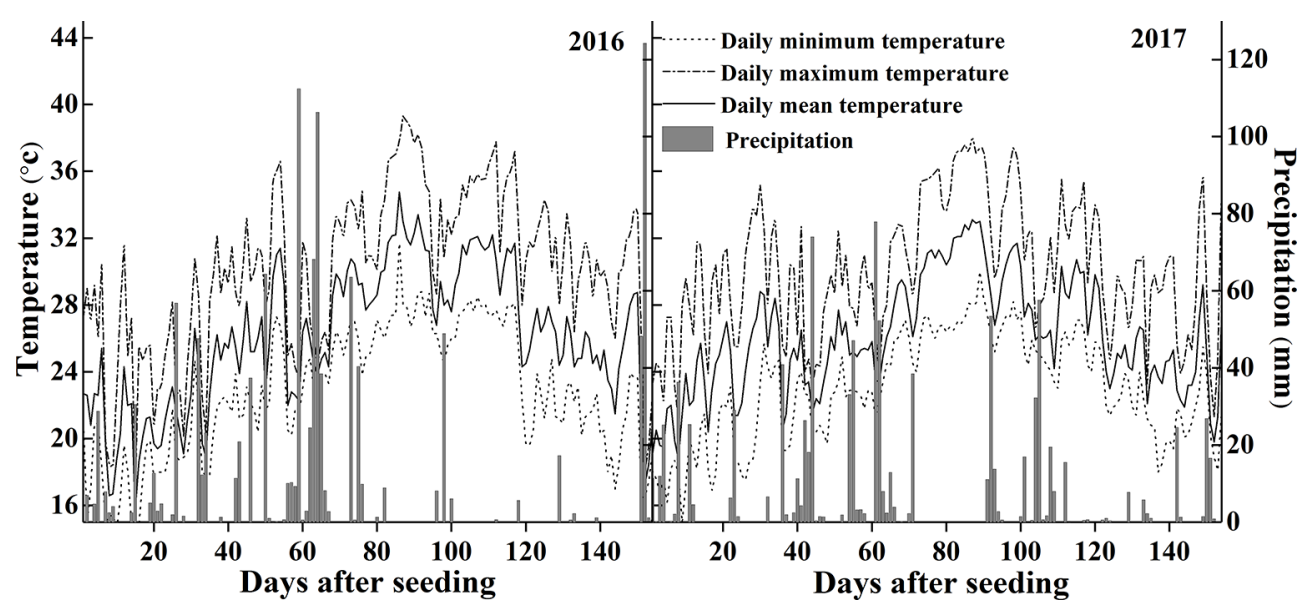

FIGURE 1 | Temperature and precipitation during the rice growing seasons in 2016 and 2017. 
The field experiment was designed as a completely randomized block experiment with four $\mathrm{N}$ (main plots) and four $\mathrm{K}$ (subplots) fertilizer rates. The $\mathrm{N}$ treatments were: $0 \mathrm{~kg} \mathrm{~N}$ $\mathrm{ha}^{-1}$ (N0), $90 \mathrm{~kg} \mathrm{~N} \mathrm{ha}^{-1}$ (N90), $180 \mathrm{~kg} \mathrm{~N} \mathrm{ha}^{-1}$ (N180), and $270 \mathrm{~kg}$ $\mathrm{N} \mathrm{ha}^{-1}$ (N270). The K treatments were: $0 \mathrm{~kg} \mathrm{~K}_{2} \mathrm{O} \mathrm{ha}{ }^{-1}$ (K0), 60 $\mathrm{kg} \mathrm{K}_{2} \mathrm{O} \mathrm{ha}^{-1}$ (K60), $120 \mathrm{~kg} \mathrm{~K}_{2} \mathrm{O} \mathrm{ha}^{-1}$ (K120), and $180 \mathrm{~kg} \mathrm{~K}_{2} \mathrm{O}$ $\mathrm{ha}^{-1}$ (K180). All treatments supplied with $90 \mathrm{~kg} \mathrm{P}_{2} \mathrm{O}_{5} \mathrm{ha}^{-1}$. Urea $(46 \% \mathrm{~N})$, superphosphate $\left(12 \% \mathrm{P}_{2} \mathrm{O}_{5}\right)$, and $\mathrm{K}$ chloride $(60 \%$ $\mathrm{K}_{2} \mathrm{O}$ ) supplied as the $\mathrm{N}, \mathrm{P}$, and $\mathrm{K}$ fertilizer sources, respectively. The $\mathrm{N}$ fertilizer was applied in three doses; $50 \%$ of the $\mathrm{N}$ fertilizer was applied as basal fertilizer (1 day before transplanting), and another $50 \%$ was divided into two equal parts and applied as topdressing at the tillering stage ( 8 days after transplanting) and filling stage (56 days after transplanting). The $\mathrm{K}$ fertilizer applied in two doses: $75 \%$ as basal fertilizer and $25 \%$ at the filling stage. The P fertilizer applied as basal fertilizer. All plots plowed and leveled after the application of basal fertilizer. The plot area was $20 \mathrm{~m}^{2}(4 \mathrm{~m} \times 5 \mathrm{~m})$. All possible combinations of the $\mathrm{N}$ and $\mathrm{K}$ fertilization levels were present in the experiment, resulting in a total number of 16 individual treatments, and each of them was repeated three times.

\section{Crop Cultivation}

Seeds of Oryza sativa L. ssp. Japonica (Shenliangyou 5814) were sown on May 22 and 20 and transplanted on June 29 and 22 in 2016 and 2017, respectively, after the application of basal fertilizer with a hill space of $0.24 \mathrm{~m} \times 0.15 \mathrm{~m}$. All plots were separated by soil bunds, which were covered with plastic film to prevent the exchange of water and fertilizer between neighboring plots. All treatments received the same fungicide, insecticide, and herbicide treatments, and no major diseases, pests, or weeds were present during the rice growing seasons. The plants were harvested on October 1, 2016, and September 30, 2017, respectively.

\section{SPAD Reading}

A chlorophyll meter (SPAD-502, Minolta Camera Co., Osaka, Japan) was used for the SPAD reading measurements of the uppermost fully expanded leaves of each plot at the stage of stem elongation (65 days after sowing). Six expanded leaves were selected from each plot. Three SPAD readings per leaf were taken around the midpoint of the lamina and $30 \mathrm{~mm}$ away on both sides of the midpoint. The SPAD reading of each plot was obtained from the average of 18 SPAD readings (Peng et al., 1993). Sampled the leaf immediately after the measurement of SPAD readings, and used to analysis the parameters as described below.

After the test of SPAD, an aerial photograph was taken by an unmanned aerial vehicle (Phantom 4PRO V2.0, DJIInnovations, Shenzhen, China) with a flight altitude of $13 \mathrm{~m}$.

\section{Morpho-Physiological Analysis: Chlorophyll Concentration, Nitrogen Concentration, Potassium Concentration, and Magnesium Concentration}

Leaf discs were obtained by a hole punch with a radius of 0.25 $\mathrm{mm}$ (the midvein was avoided) at stem elongation (65 days after sowing). Some of the leaf discs were used to measure the chlorophyll concentrations according to the method of Arnon (1949). Placed the other part of the leaf discs in an oven for 30 min at $105^{\circ} \mathrm{C}$ to stop metabolic activities and then dried at $70^{\circ} \mathrm{C}$ to a constant weight. All dried samples were ground, then digested by $\mathrm{H}_{2} \mathrm{SO}_{4}$ (purity of $98 \%$ ) and $\mathrm{H}_{2} \mathrm{O}_{2}$ (purity of $30 \%$ ) (for the analysis of $\mathrm{N}$ and $\mathrm{K}$ ) on an open digestion furnace (LWY84B, Sichuan, China) with a temperature of $380^{\circ} \mathrm{C}$ and extracted with $4 \mathrm{M} \mathrm{HNO}_{3}$ (purity of $68 \%$ ) for $4 \mathrm{~h}$ (for the analysis of Mg) (Thomas et al., 1967; Neuhaus et al., 2013). The N concentration in the digestion solution was determined by a continuous flow analysis (AA3, Seal Analytical Inc., Southampton, UK). The $\mathrm{K}$ concentration in the digestion solution was determined by a flame photometer (M-410, Sherwood Scientific Ltd., Cambridge, UK). The $\mathrm{Mg}$ concentration in the extract solution was determined by an atomic absorption spectrometer (Fast Sequential Atomic Absorption Spectrometer, AAS, AA240FS, Varian, California, USA).

\section{Anatomical Analysis: Leaf Thickness, Chloroplast Number, and Chloroplast Size}

Anatomical analysis was down in 2017. Leaf segments (approximately $1 \mathrm{~mm} \times 4 \mathrm{~mm}$ ) were cut from the middle of the leaves (the midvein was avoided) using a blade at stem elongation (65 days after sowing), fixed immediately in $2.5 \%$ glutaraldehyde (v/v) in $0.1 \mathrm{~mol} \mathrm{~L}^{-1}$ phosphate buffer ( $\mathrm{pH}$ 7.4), and then post fixed with $2 \%$ osmium tetroxide for $2 \mathrm{~h}$. Leaf segments were embedded in Spurr's epoxy resin (Sigma-Aldrich, St. Louis, USA). Semithin leaf cross sections were stained with toluidine blue and observed at $200 \times$ magnification with a light microscope (IX71, Olympus Optical, Tokyo, Japan). Soft Imaging System Software (version 1.15.3, Panoramic Viewer, 3DHISTECH, Budapest, Hungary) was used for the observation and photography. Leaf thickness was measured using Image-Pro Plus (version 6.0, Media Cybernetics, Maryland, USA).

Ultrathin leaf sections ( $90 \mathrm{~nm}$ thick) were examined for the ultrastructural observation of chloroplasts using a transmission electron microscope (H-7650, Hitachi, Japan) after staining the leaf sections with $2 \%$ uranyl acetate $(w / v)$ and lead citrate. Chloroplast number was counted, and the chloroplast length and thickness were measured using Image-Pro Plus. The chloroplast surface area was calculated according to the Cesaro formula:

$$
S=4 \times \pi \times \sqrt[3]{\left(L \times T^{2}\right)^{2}}
$$

where $\mathrm{L}=0.5 \times$ chloroplast length, and $\mathrm{T}=0.5 \times$ chloroplast thickness.

\section{Determination of Total Leaf Area, Total Leaf Dry Mass, Specific Leaf Weight (SLW), Total Chlorophyll Concentration, and Grain Yield}

Six plants were sampled at stem elongation (65 days after sowing). All green leaves were removed from the stem, and the single leaf area was calculated as single leaf area $=$ leaf length $\times$ 
leaf width $\times 0.75$ (Wang et al., 2007). The leaves were placed in an oven for $30 \mathrm{~min}$ at $105^{\circ} \mathrm{C}$ to stop metabolic activities and then oven dried at $70^{\circ} \mathrm{C}$ to a constant weight. Two hundred dry leaf discs from section 2.4 were weighed, and the SLW was calculated as SLW = the weight of 200 leaf discs/the area of 200 leaf discs. The area of the leaf discs $=\pi \times r^{2}$, where $r$ is $2.5 \mathrm{~mm}$. The total chlorophyll concentration was calculated based on the chlorophyll concentration of the leaves and the total leaf area.

Grain yield was determined from an area of $10 \mathrm{~m}^{2}$ in the center of each plot on October 1, 2016 and September 30, 2017. Grain moisture concentration was measured using a moisture meter and adjusted to $0.14 \mathrm{~g} \mathrm{H}_{2} \mathrm{O} \mathrm{g}^{-1}$ fresh weight.

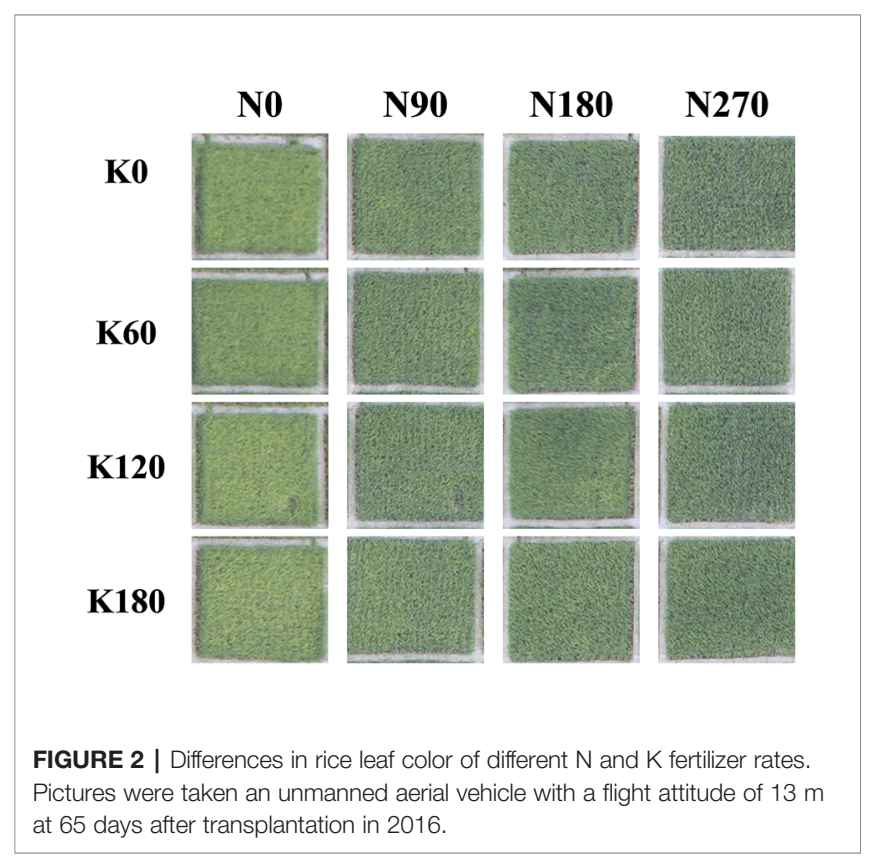

\section{Statistical Analyses}

The data are expressed as the means \pm standard deviation. Analysis of variance (ANOVA) is performed using SPSS 18.0 (SPSS, Chicago, IL, USA) to determine the significant effects of the $\mathrm{N}$ and $\mathrm{K}$ treatments on the described parameters. The least significant difference (LSD) test is used to compare significant differences based on $P$-values $\leq 0.05$. All the figures and regression analyses was performed using Origin Pro 8.5 software (Origin Lab Corporation, Northampton, MA, USA).

\section{RESULTS}

Figure 2 shows the phenomenon in the field that how the rice leaf greenness varied with differences in $\mathrm{N}$ and $\mathrm{K}$ rates. Leaf greenness increased with increasing $\mathrm{N}$ and decreased with increasing K. Several physiological and anatomical properties were studied in this paper to explain this phenomenon.

\section{Leaf SPAD Reading and Chlorophyll Concentration}

The SPAD reading and chlorophyll concentration were used to quantify the leaf greenness. Increasing $\mathrm{N}$ fertilizer rates significantly increased the SPAD reading (Figure 3 ). The highest mean SPAD reading reached at $270 \mathrm{~N}$ and $0 \mathrm{~kg} \mathrm{ha}^{-1}$. Compared to the N0 treatment, the application of $270 \mathrm{~kg} \mathrm{~N} \mathrm{ha}^{-1}$ increased the SPAD readings by $15.3 \%, 18.1 \%, 17.4 \%$, and $17.7 \%$ in 2016 and by $24.3 \%, 23.5 \%, 21.0$, and $18.4 \%$ in 2017, respectively, at the four $\mathrm{K}$ rates. Within one $\mathrm{N}$ rate, increasing $\mathrm{K}$ application decreased the SPAD reading. The lowest mean SPAD reading reached at $0 \mathrm{~N}$ and $180 \mathrm{~K} \mathrm{~kg} \mathrm{ha}^{-1}$. Compared to the $\mathrm{K} 0$ treatment, the application of $180 \mathrm{~kg} \mathrm{~K}_{2} \mathrm{O} \mathrm{ha}{ }^{-1}$ decreased the SPAD reading by $6.3 \%, 12.5 \%, 6.4 \%$, and $4.3 \%$ in 2016 and by $6.4 \%$, $8.4 \%, 11.5 \%$, and $10.7 \%$ in 2017 , respectively, at the four $\mathrm{N}$ rates.

Similar to the SPAD reading, the chlorophyll concentration significantly increased with increasing $\mathrm{N}$ rates (Figure 4).

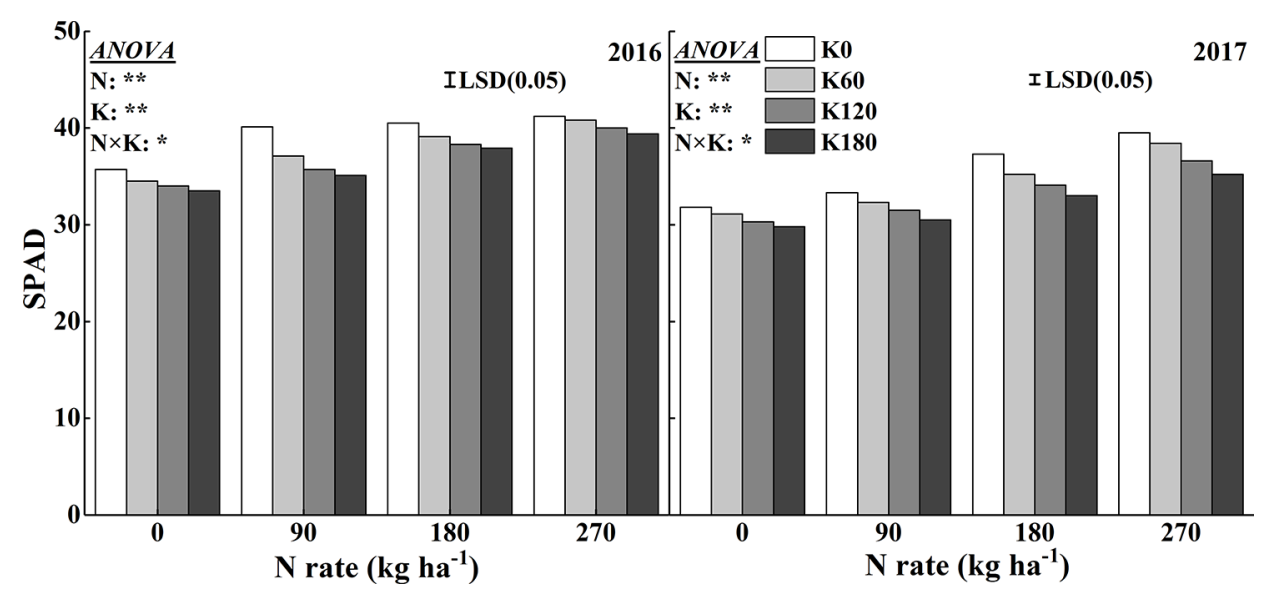

FIGURE 3 | Effects of $\mathrm{N}$ and $\mathrm{K}$ rates on SPAD of rice leaves. LSD (0.05) represents the least significant difference among the treatments at $P<0.05$. 


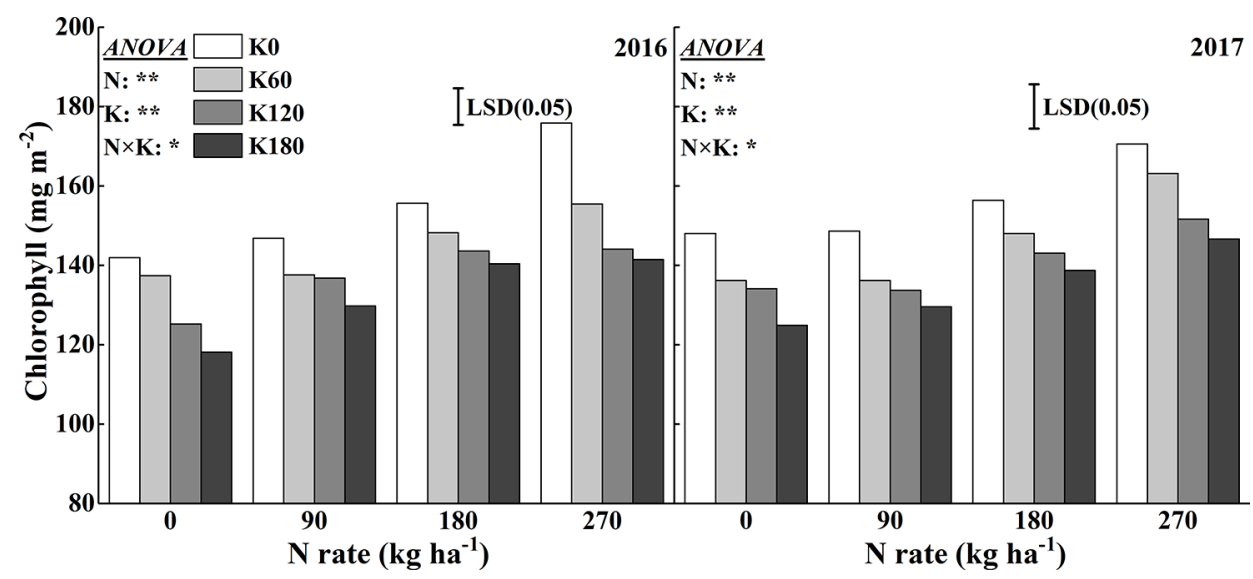

FIGURE 4 | Effects of $\mathrm{N}$ and $\mathrm{K}$ rates on the chlorophyll concentration of rice leaves. Least significant difference (LSD) (0.05) represents the least significant difference among the treatments at $P<0.05$.

Compared to the N0 treatment, the application of $270 \mathrm{~kg} \mathrm{~N} \mathrm{ha}^{-1}$ increased the chlorophyll concentration by $19.7 \%, 13.1 \%, 15.1 \%$, and $19.8 \%$ in 2016 and $17.9 \%, 19.8 \%, 16.0 \%$, and $20.6 \%$ in 2017 , respectively, at the four $\mathrm{K}$ rates. Within a $\mathrm{N}$ rate, increasing the $\mathrm{K}$ rates decreased the chlorophyll concentrations. Compared to the $\mathrm{K} 0$ treatment, the application of $180 \mathrm{~kg} \mathrm{~K}_{2} \mathrm{O} \mathrm{ha}{ }^{-1}$ decreased the chlorophyll concentration by $19.6 \%, 8.5 \%, 9.8 \%$, and $19.5 \%$ in 2016 and by $16.0 \%, 12.8 \%, 13.1 \%$, and $14.1 \%$ in 2017 , respectively, at the four $\mathrm{N}$ rates.

\section{Leaf $\mathrm{N}, \mathrm{K}$, and $\mathrm{Mg}$ Concentration}

Figure 5 shows the variations in leaf $\mathrm{N}, \mathrm{K}$, and $\mathrm{Mg}$ concentrations for the combined use of $\mathrm{N}$ and $\mathrm{K}$. There were significant interaction effects of $\mathrm{N}$ and $\mathrm{K}$ on leaf $\mathrm{N}, \mathrm{K}$, and $\mathrm{Mg}$ concentrations. The concentration of $\mathrm{N}$ in leaves consistently increased as more $\mathrm{N}$ applied, while it decreased as more $\mathrm{K}$ applied. Compared to the N0 treatment, the application of 270 $\mathrm{kg} \mathrm{N} \mathrm{ha}^{-1}$ increased the $\mathrm{N}$ concentration by $46.6 \%, 44.8 \%, 47.8 \%$, and $46.0 \%$ in 2016 and $32.1 \%, 32.3 \%, 35.4 \%$, and $30.8 \%$ in 2017 , respectively, at the four $\mathrm{K}$ rates. Within the same $\mathrm{N}$ rate, increasing $\mathrm{K}$ rate decreased the leaf $\mathrm{N}$ concentration. The lowest mean $\mathrm{N}$ concentration was reached at $0 \mathrm{~N}$ and $180 \mathrm{~K}$ $\mathrm{kg} \mathrm{ha}^{-1}$. Compared to the K0 treatment, the application of $180 \mathrm{~kg}$ $\mathrm{K}_{2} \mathrm{O}$ ha $^{-1}$ decreased the leaf $\mathrm{N}$ concentration by $6.3 \%, 12.6 \%$, $11.5 \%$, and $6.7 \%$ in 2016 and by $12.7 \%, 11.4 \%, 14.6 \%$, and $13.6 \%$ in 2017, respectively, at the four $\mathrm{N}$ rates. The $\mathrm{Mg}$ concentration showed the same trend as that of the leaf $\mathrm{N}$ concentration. Compared to the N0 treatment, the application of $270 \mathrm{~kg} \mathrm{~N} \mathrm{ha}^{-1}$ increased the $\mathrm{Mg}$ concentration by $18.1 \%, 7.0 \%, 6.0 \%$, and $5.5 \%$ in 2016 and by $47.5 \%, 49.4 \%, 31.5 \%$, and $19.3 \%$ in 2017 , respectively, at the four $\mathrm{K}$ rates. Within the same $\mathrm{N}$ rate, increasing $\mathrm{K}$ rate also decreased the leaf $\mathrm{Mg}$ concentration. The lowest mean $\mathrm{Mg}$ concentration was reached for the combined use of $0 \mathrm{~kg} \mathrm{~N} \mathrm{ha}^{-1}$ and $180 \mathrm{~kg} \mathrm{~K}_{2} \mathrm{O} \mathrm{ha}{ }^{-1}$. Compared to the $\mathrm{K} 0$ treatment, the application of $180 \mathrm{~kg} \mathrm{~K}_{2} \mathrm{O} \mathrm{ha}^{-1}$ decreased the leaf $\mathrm{Mg}$ concentration by $16.0 \%, 12.3 \%, 10.7 \%$, and $25.0 \%$ in 2016 and $9.5 \%, 10.6 \%, 15.1 \%$, and $26.8 \%$ in 2017 , respectively, at the four $\mathrm{N}$ rates.

\section{Chloroplast Development}

The chloroplast ultrastructure was significantly influenced for the combined supply of $\mathrm{N}$ and $\mathrm{K}$ (Figures $\mathbf{6}$ and 7). The application of $\mathrm{N}$ significantly enlarged the chloroplast, while the application of $\mathrm{K}$ significantly changed the chloroplast shape from an irregular large oval to a regular spindle shapes (Figure 6). Another characteristic was that the deficiency in $\mathrm{K}$ led to swollen chloroplasts, which were irregularly arranged in the cells. The application of $\mathrm{N}$ increased chloroplast length, thickness, and single chloroplast surface area, while the application of $\mathrm{K}$ decreased all such parameters (Figure 7). Chloroplast length, chloroplast thickness, and single chloroplast surface area were increased by $2.6-9.8 \%, 3.4-25.0 \%$, and $6.4-43.0 \%$, respectively, when plants were fertilized with $270 \mathrm{~kg} \mathrm{~N} \mathrm{ha}^{-1}$ compared with $\mathrm{N} 0$ treatment. The chloroplast length, thickness, and single chloroplast surface area decreased by $1.5-6.7 \%, 13.8-22.7 \%$, and $18.9-32.2 \%$, respectively, when the $\mathrm{K}$ rate increased from 0 to $180 \mathrm{~kg} \mathrm{~K}_{2} \mathrm{O} \mathrm{ha}{ }^{-1}$ within the same $\mathrm{N}$ rate. The application of $\mathrm{N}$ and $\mathrm{K}$ both significantly increased the chloroplast number per unit leaf area. The chloroplast number per unit leaf area was increased by $13.2-44.0 \%$ and $11.4-19.6 \%$ with the application of $\mathrm{N}$ and $\mathrm{K}$, respectively.

\section{Leaf Thickness and SLW}

Leaf thickness and SLW were analyzed to reflect the effects of $\mathrm{N}$ and $\mathrm{K}$ on leaf anatomy (Figure 8). The application of $\mathrm{N}$ and $\mathrm{K}$ increased leaf thickness. Nitrogen application increased leaf thickness by $2.8-9.8 \%$ compared to that of the N0 treatment, and within $\mathrm{N}$ rate, $\mathrm{K}$ application increased leaf thickness by 2.0 $4.6 \%$. The greatest leaf thickness reached at an application rate of $270 \mathrm{~kg} \mathrm{~N} \mathrm{ha}^{-1}$, but within this treatment, $\mathrm{K}$ application had no significant effect. The SLW was significantly influenced by the application of $\mathrm{N}$ and $\mathrm{K} . \mathrm{N}$ application decreased the SLW, and 


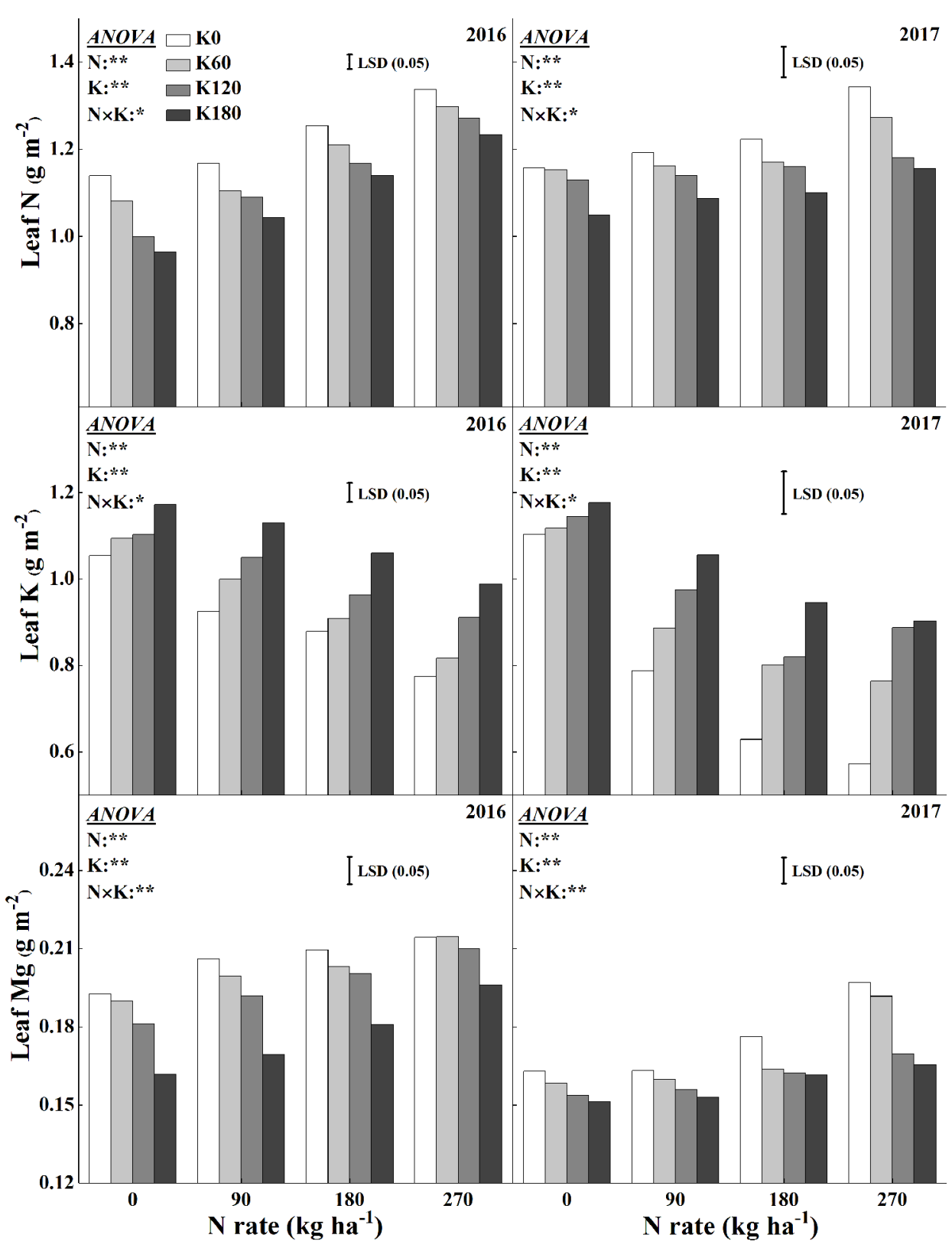

FIGURE 5 | Effects of $\mathrm{N}$ and $\mathrm{K}$ rates on leaf N, K, and Mg concentrations. Least significant difference (LSD) (0.05) represents the least significant difference among the treatments at $P<0.05$.

within $\mathrm{N}$ rate, $\mathrm{K}$ application decreased the SLW. The SLW was less sensitive to $\mathrm{K}$ rates than to $\mathrm{N}$ rates, as a significant decrease in SLW was observed only at the highest $\mathrm{K}$ application rate of $180 \mathrm{~kg} \mathrm{~K}_{2} \mathrm{O}$ $\mathrm{ha}^{-1}$. The SLW decreased on average by $2.9-11.1 \%$ and $2.3-9.9 \%$, respectively, for the application of $\mathrm{N}$ and $\mathrm{K}$ compared to that for the N0 and K0 treatments. The lowest SLW observed at the highest fertilizer rates $\left(270 \mathrm{~kg} \mathrm{~N} \mathrm{ha}^{-1}\right.$ combined with $180 \mathrm{~kg} \mathrm{~K}_{2} \mathrm{O} \mathrm{ha}^{-1}$ ).

\section{Leaf Development and Grain Yield}

The increase in $\mathrm{N}$ and $\mathrm{K}$ rates not only increased the leaf area index (LAI), but also increased the leaf dry mass and chlorophyll accumulation (Table 1). The lowest LAI, leaf dry mass, and chlorophyll accumulation values were observed in rice plants without N and K. Compared to NOK0 treatment, the maximum increase rate of LAI, leaf dry mass, and chlorophyll accumulation was $183.9 \%, 181.6 \%$, and $178.7 \%$ in 2016 and $156.1 \%, 181.6 \%$, and $156.1 \%$ in 2017 , respectively. The application of $\mathrm{N}$ increased the LAI, the leaf dry mass, and chlorophyll accumulation by $60.5 \%, 73.2 \%$, and $79.9 \%$ in 2016 and $71.5 \%, 111.2 \%$, and $71.5 \%$ in 2017 . The application of $\mathrm{K}$ increased these values by $28.2 \%, 18.8 \%$, and $13.7 \%$ in 2016 and $25.8 \%, 18.7 \%$, and $25.8 \%$ in 2017 , respectively. There were 

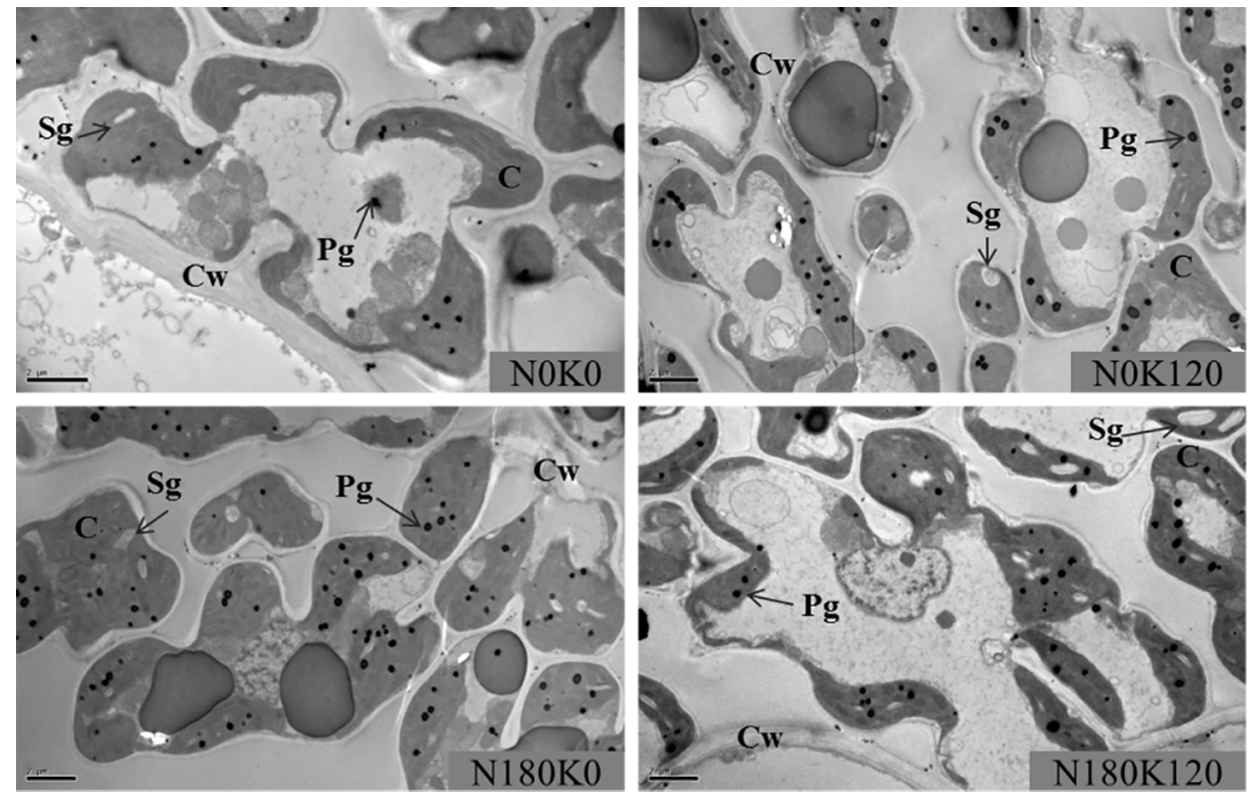

FIGURE 6 | Transmission electron microscopy images of leaves plants fertilized with different $\mathrm{N}$ and $\mathrm{K}$ rates. C, chloroplast; Cw, cell wall; Pg, plastoglobuli; Sg, starch grain. The scale bar depicts $2 \mu \mathrm{m}$.

significant interaction effects of $\mathrm{N}$ and $\mathrm{K}$ on LAI, leaf dry mass, and chlorophyll accumulation.

Figure 9 shows the variation in grain yields in response to the application of $\mathrm{N}$ and $\mathrm{K}$. There were significant effects of $\mathrm{N}$ and $\mathrm{K}$ and their interaction effects on grain yield. Grain yield increased with increasing $\mathrm{N}$ and $\mathrm{K}$ rates. When compared to the yield from the N0 and K0 treatments, the grain yield increased on average by $11.8-22.8 \%$ and $6.7-13.7 \%$ in 2016 and by $17.5-21.4 \%$ and $6.0-12.1 \%$ in 2017, respectively, with the application of $\mathrm{N}$ and $\mathrm{K}$. The combined use of $180 \mathrm{~kg} \mathrm{~N}^{-1}$ with 120 and $180 \mathrm{~kg} \mathrm{~K}_{2} \mathrm{O}$ $\mathrm{ha}^{-1}$ and $270 \mathrm{~kg} \mathrm{~N} h a^{-1}$ with 60,120 , and $180 \mathrm{~kg} \mathrm{~K}_{2} \mathrm{O} \mathrm{ha}^{-1}$ achieved relatively high grain yields.

Figure 10 shows the highly positive correlations between leaf dry mass, LAI, chlorophyll accumulation, and chlorophyll concentration with grain yield across the 2 years, which indicates that there were significant effects of leaf area, leaf dry mass and leaf chlorophyll accumulation on grain yield, and the chlorophyll concentration in this study did not show significant correlation with grain yield.

\section{DISCUSSION}

\section{Effects of Nitrogen and Potassium on Leaf Greenness}

A visual inspection of leaf greenness revealed darker green colors with increasing $\mathrm{N}$ rates. Analyses of SPAD readings and chlorophyll concentrations could verify this visual observation. Many studies have investigated the relationships between leaf $\mathrm{N}$ concentrations and SPAD readings in the past 20 years, and it has been universally accepted that there were significant relationships between leaf $\mathrm{N}$ concentrations and SPAD readings as well as leaf chlorophyll concentrations (Castelli et al., 1996; Huang et al., 2008; Lavres and Monteiro, 2010; Wang et al., 2014). In addition to SPAD-502, visible and near infrared (VIS-NIR) hyperspectral imaging system, $18 \%$-gray dark green color index (DGCI), and so on had been used to diagnose the leaf $\mathrm{N}$ status (Rotbart et al., 2013; Zhang et al., 2013; Confalonieri et al., 2015; Yuan et al., 2016). Numerous studies have shown that the application of $\mathrm{N}$ could increase chlorophyll concentrations (Li et al., 2009; Gu et al., 2017; Liu et al., 2017). However, there is considerable debate on whether the application of $\mathrm{K}$ could either increase or decrease the leaf chlorophyll concentrations. Studies on cotton and oilseed rape have shown that K application could increase chlorophyll concentrations (Zhao et al., 2001; Hu et al., 2016). Reduced leaf chlorophyll concentration under $\mathrm{K}$ deficiency has been reported in cotton, olive trees, and legumes (Collins and Duke, 1981; Zhao et al., 2001; Erel et al., 2015). In contrast, Jia et al. (2008) reported that leaf chlorophyll concentration increased at moderate $\mathrm{K}$ deficiency in rice. In the present study, increasing $K$ rates decreased the SPAD readings and chlorophyll concentrations irrespective of the application of $\mathrm{N}$. This phenomenon might be the result of the uptake antagonism between $\mathrm{K}^{+}$and $\mathrm{NH}_{4}{ }^{+}$. Ammonia is the major $\mathrm{N}$ source in paddy fields, and $\mathrm{NH}_{4}{ }^{+}$and $\mathrm{K}^{+}$have similar hydrated diameters and charges, resulting in antagonistic relationships between these two ions (Zhang et al., 2010; Coskun et al., 2016). 


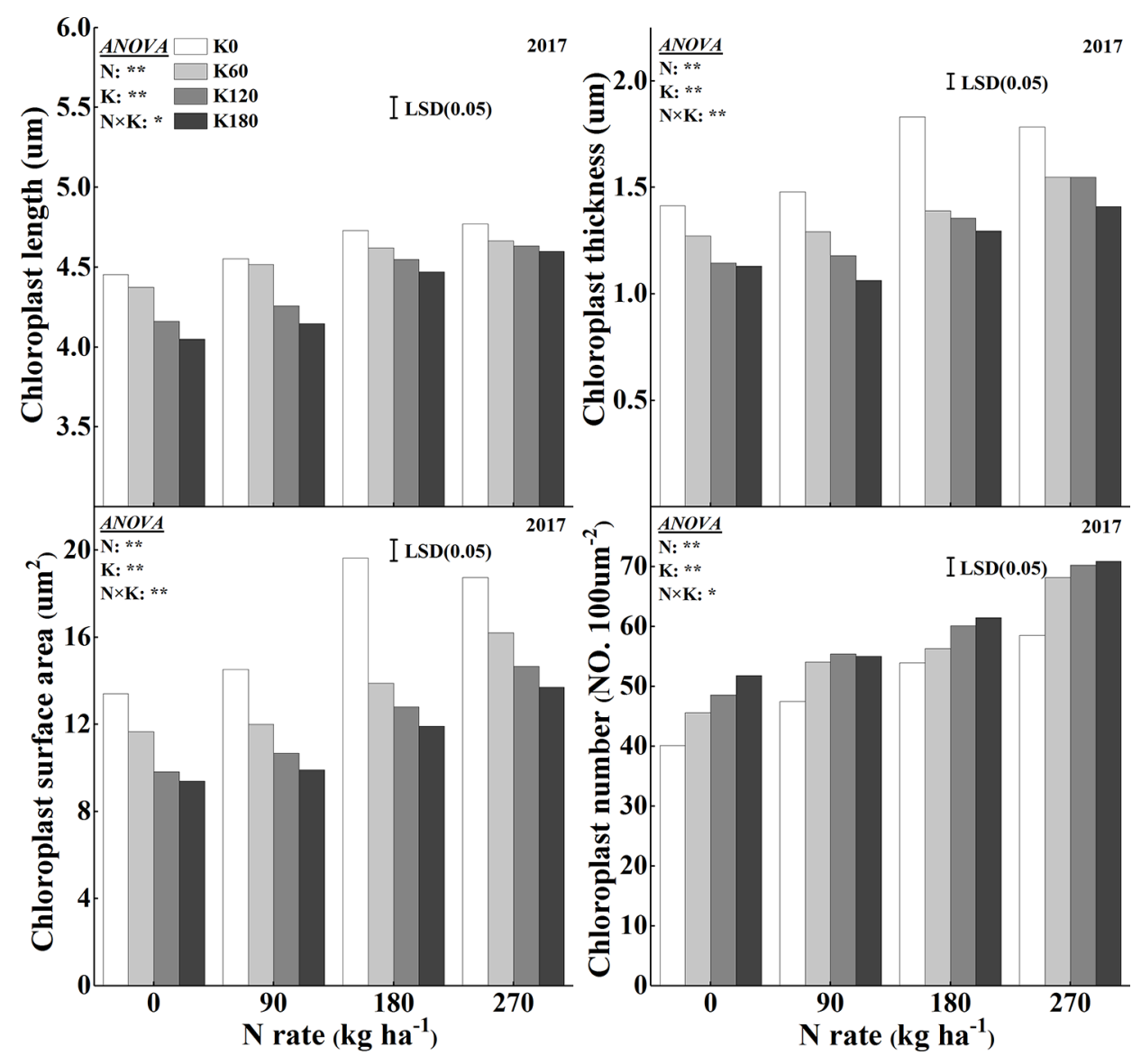

FIGURE 7 | Effects of $\mathrm{N}$ and $\mathrm{K}$ rates on length, thickness, surface area, and number of chloroplasts. Least significant difference (LSD) (0.05) represents the least significant difference among the treatments at $P<0.05$.

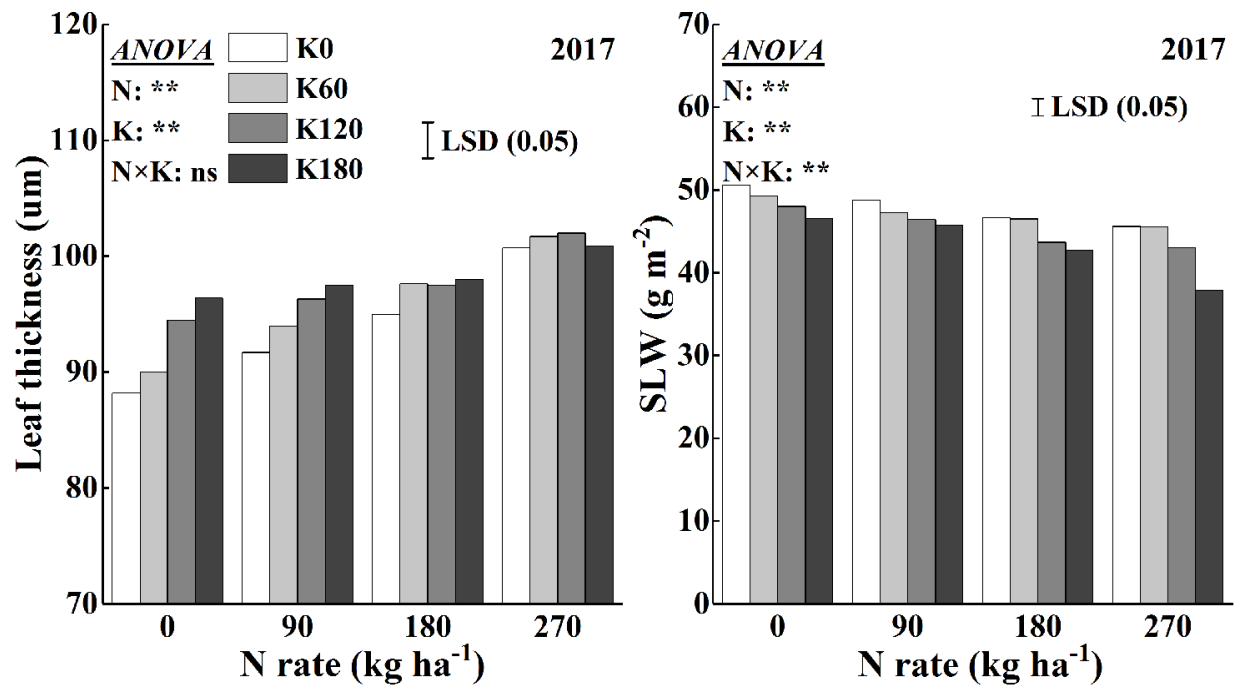

FIGURE 8 | Effects of $\mathrm{N}$ and $\mathrm{K}$ rates on leaf thickness and specific leaf weight (SLW). Least significant difference (LSD) (0.05) represents the least significant difference among the treatments at $P<0.05$. 
TABLE 1 | Effects of nitrogen and potassium rates on leaf area index (LAl), leaf dry mass and chlorophyll accumulation.

\begin{tabular}{|c|c|c|c|c|c|c|c|}
\hline \multicolumn{2}{|c|}{ Treatments } & \multicolumn{3}{|c|}{2016} & \multicolumn{3}{|c|}{2017} \\
\hline & & LAI & $\begin{array}{l}\text { Leaf dry mass } \\
\left.\quad \text { (g plant }^{-1}\right)\end{array}$ & $\begin{array}{l}\text { Chlorophyll } \\
\text { accumulation } \\
\text { (g plant }^{-1} \text { ) }\end{array}$ & LAI & $\begin{array}{l}\text { Leaf dry mass } \\
\quad\left(\text { g plant }^{-1}\right)\end{array}$ & $\begin{array}{l}\text { Chlorophyll accumulation } \\
\left.\text { (g plant }{ }^{-1}\right)\end{array}$ \\
\hline \multirow[t]{4}{*}{ NO } & KO & 1.62 j & $3.13 i$ & $8.84 h$ & $1.67 \mathrm{j}$ & $2.40 \mathrm{j}$ & $9.10 \mathrm{j}$ \\
\hline & K60 & $2.16 \mathrm{i}$ & $4.02 \mathrm{~h}$ & $10.77 \mathrm{~g}$ & $1.85 j$ & $2.50 \mathrm{ij}$ & 10.08 j \\
\hline & K120 & 2.32 hi & $4.36 \mathrm{~h}$ & $10.96 \mathrm{~g}$ & $2.17 \mathrm{i}$ & $2.80 i$ & $11.81 \mathrm{i}$ \\
\hline & K180 & $2.54 \mathrm{gh}$ & $4.86 \mathrm{~g}$ & $11.12 \mathrm{~g}$ & $2.27 \mathrm{hi}$ & $3.27 \mathrm{~h}$ & $12.39 \mathrm{hi}$ \\
\hline \multirow[t]{4}{*}{ N90 } & KO & $2.45 \mathrm{~h}$ & $5.04 \mathrm{fg}$ & $12.87 f$ & $2.51 \mathrm{~h}$ & $3.87 \mathrm{~g}$ & $13.67 \mathrm{~h}$ \\
\hline & K60 & $2.76 \mathrm{fg}$ & $5.41 \mathrm{f}$ & 14.06 ef & $2.87 \mathrm{~g}$ & $4.27 \mathrm{f}$ & $15.66 \mathrm{~g}$ \\
\hline & K120 & 2.96 ef & 5.85 e & 15.04 e & 3.08 efg & 4.40 ef & 16.76 efg \\
\hline & K180 & $3.02 \mathrm{e}$ & $6.11 \mathrm{e}$ & 14.52 ef & 3.24 de & $4.73 \mathrm{e}$ & $17.64 \mathrm{de}$ \\
\hline \multirow[t]{4}{*}{ N180 } & KO & 3.01 ef & $6.19 \mathrm{e}$ & $17.31 d$ & $2.91 \mathrm{fg}$ & $5.10 \mathrm{~d}$ & $15.85 \mathrm{fg}$ \\
\hline & K60 & $3.44 d$ & $7.08 d$ & $18.64 d$ & $3.35 \mathrm{~cd}$ & $5.87 \mathrm{c}$ & $18.27 \mathrm{~cd}$ \\
\hline & K120 & $3.50 \mathrm{~d}$ & $7.76 \mathrm{c}$ & $18.90 \mathrm{~d}$ & $3.95 b$ & $6.20 \mathrm{bc}$ & $21.51 \mathrm{~b}$ \\
\hline & K180 & $4.19 b$ & 8.03 bc & $21.82 \mathrm{bc}$ & $4.07 \mathrm{ab}$ & $6.47 \mathrm{~b}$ & $22.17 \mathrm{ab}$ \\
\hline \multirow[t]{7}{*}{ N270 } & KO & $3.29 d$ & $7.86 \mathrm{bc}$ & $21.44 \mathrm{c}$ & 3.16 def & $6.23 \mathrm{~b}$ & 17.22 def \\
\hline & K60 & $3.89 \mathrm{c}$ & $8.19 b$ & 22.38 bc & $3.60 \mathrm{c}$ & $6.37 \mathrm{~b}$ & $19.63 \mathrm{C}$ \\
\hline & K120 & $4.61 \mathrm{a}$ & $8.80 \mathrm{a}$ & $24.60 \mathrm{a}$ & $3.94 b$ & $7.30 \mathrm{a}$ & $21.49 b$ \\
\hline & K180 & $4.48 \mathrm{a}$ & 8.69 a & $23.46 \mathrm{ab}$ & $4.28 \mathrm{a}$ & $7.40 \mathrm{a}$ & $23.32 \mathrm{a}$ \\
\hline & & $\star \star$ & $\star \star$ & $\star \star$ & $\star \star$ & $\star \star$ & $\star \star$ \\
\hline & & $\star \star$ & $\star *$ & $\star \star$ & $\star \star \star$ & $\star \star$ & $\star \star$ \\
\hline & & $\star \star$ & * & * & * & $\star \star \star$ & * \\
\hline
\end{tabular}

Different lowercase letters in the same column indicate significant differences between different treatments. ${ }^{*}$ and ${ }^{* *}$ indicate significance at $P<0.05$ and $P<0.01$.

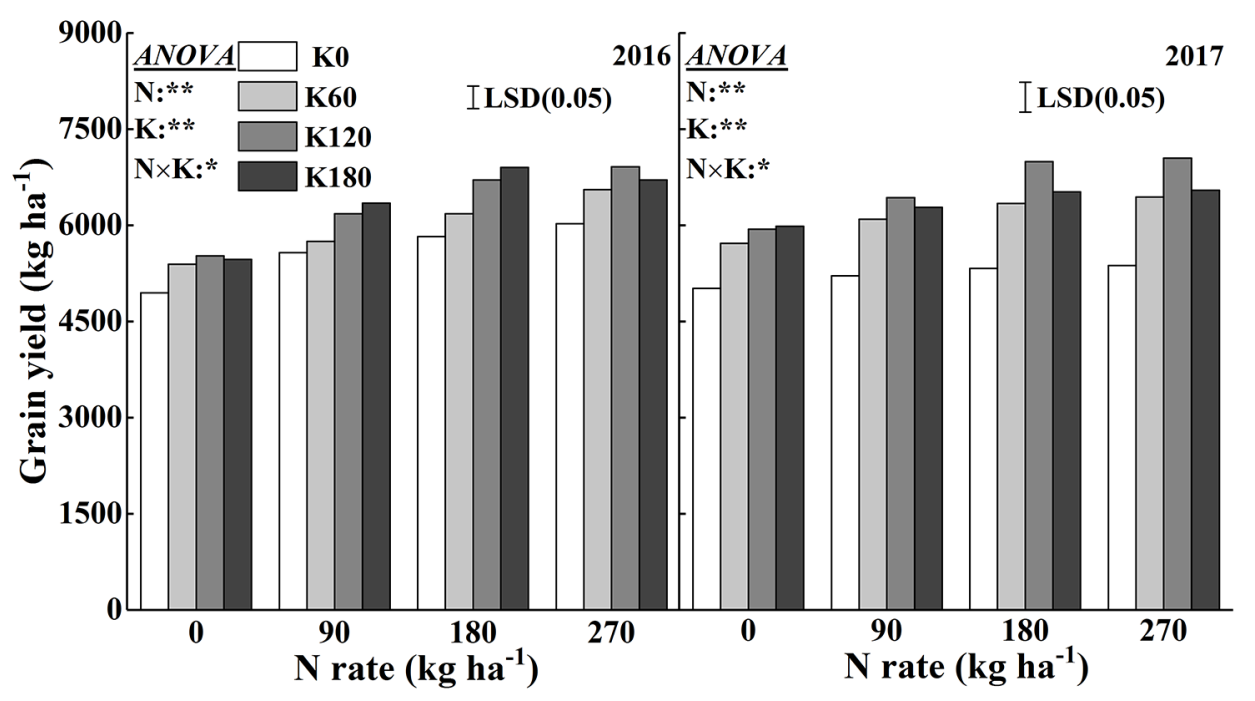

FIGURE 9 | Effects of $\mathrm{N}$ and $\mathrm{K}$ rates on grain yield of rice in 2016 and 2017. Least significant difference (LSD) (0.05) represents the least significant difference among the treatments at $P<0.05$.

Our results indicated that with the increase in $\mathrm{K}$, leaf $\mathrm{K}$ concentrations increased while the $\mathrm{N}$ and $\mathrm{Mg}$ concentrations decreased. As both $\mathrm{N}$ and $\mathrm{Mg}$ are structural elements of chlorophyll, they have substantial effects on chlorophyll synthesis (Xiong et al., 2015; Ceylan et al., 2016; Tränkner et al., 2018). Approximately $50 \%$ of leaf $\mathrm{N}$ invested in the form of photosynthetic proteins, including for the important components in involved in light harvesting, such as chlorophylls (Xiong et al., 2015).

\section{Leaf Anatomical Characteristics on Leaf Greenness}

The chloroplast number and size increased significantly with the $\mathrm{N}$ supplementation (Laza et al., 1993; Xiong et al., 2015). In line with this, in our results, the application of $\mathrm{N}$ increased chloroplast numbers per leaf area. However, the application of $\mathrm{K}$ could further increase the chloroplast number per leaf area, which is contrary to the results that $\mathrm{K}$ application decreased chlorophyll concentrations. Regarding the morphology of the 


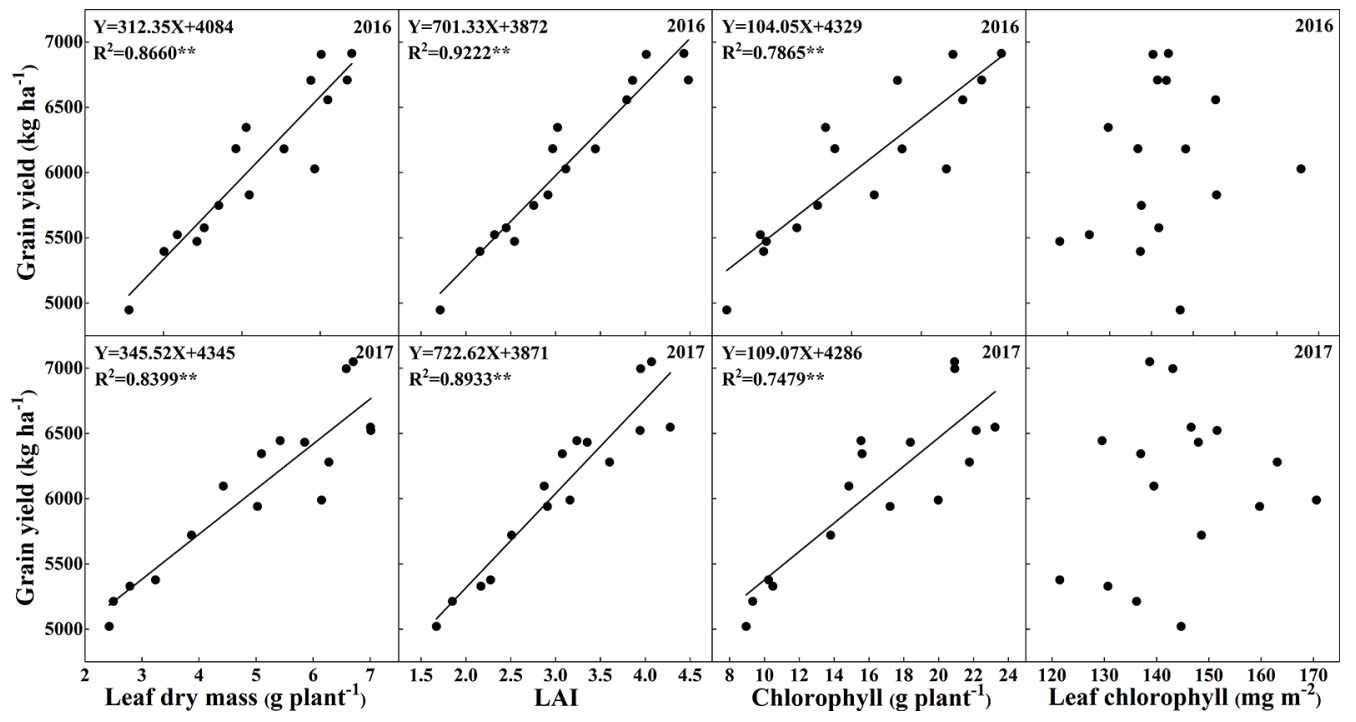

FIGURE 10 | Relationships of total leaf dry mass, leaf area index, chlorophyll concentrations, and total chlorophyll accumulation rates with grain yield.

chloroplasts, the application of $\mathrm{K}$ had different effects. Our data showed that chloroplast thickness and surface area decreased with the supplementation of $\mathrm{K}$ at a specific $\mathrm{N}$ rate, and that chloroplasts were swollen and irregularly arranged in the cells (Figure 6). The thinner chloroplasts under sufficient $\mathrm{K}$ application might be the result of proper thylakoid membrane stacking, which is a process that requires $\mathrm{K}$ ions to screen negative surface charges of the thylakoid membranes. Irregularly arranged thylakoids and swollen chloroplasts were observed in K-deficient cotton plants (Hu et al., 2016). Furthermore, the increased chloroplast thickness under the low $\mathrm{N}$ or $\mathrm{K}$ rates might be the result of the starch granules accumulation in the chloroplast (Figure 6). Large starch granules were observed in chloroplasts of N-deficient rice and K-deficient cotton and maize (Hall et al., 1972; Laza et al., 1993; Zhao et al., 2001; Li et al., 2013). The accumulation of starch inside the chloroplasts is most likely due to the lower supply of $\mathrm{N}$, which weakens the demand for $\mathrm{C}$ compounds. It had been reported that the increase of $\mathrm{N}$ rates promoted the development of chloroplast and decreased the starch granules in chloroplast (Laza et al., 1993; Li et al., 2013; Gu et al., 2017). On the other hand, $\mathrm{K}$ deficiency significantly decreases the remobilization of carbohydrate, increases leaf carbohydrate concentrations, and starch granules (Jia et al., 2008; Gerardeaux et al., 2009; Wang et al., 2012). Sucrose and starch are the main products of photosynthesis, which provide carbon and energy for plant growth. Starch is a temporarily stored carbohydrate, which can be converted into source (Gandin et al., 2009). It had been reported that $\mathrm{K}$ deficiency lead to significantly higher hexose, sucrose, and starch concentrations (Hu et al., 2015; Hu et al., 2017). An accumulation of starch inside the chloroplasts might also be the reason for the increased SLW under low $\mathrm{K}$ application rates. According to Pettigrew (2008), a deficiency in $\mathrm{K}$ decreased the transport of photosynthetic assimilates out of leaves, which may lead to the increase in SLW. Tränkner et al. (2018) also reported that a deficiency in $\mathrm{K}$ restricted the phloem loading of sucrose resulting in an accumulation of sucrose in source tissues. Zhao et al. (2001) reported that $\mathrm{K}$-deficient cotton leaves had less intercellular air space than that supplied with sufficient K. Sims et al. (1998) showed that increased $\mathrm{N}$ levels could improve leaf thickness by increasing the mesophyll cell layer with only small changes in total epidermal thickness. However, a higher $\mathrm{N}$ supply leads to a larger leaf area, which might be a reason for the decreases of SLW.

\section{Relationship Between Leaf Greenness and Grain Yield}

The leaves of rice are responsible for capturing solar energy, so a larger leaf area could capture more light, which in turn is an important factor for the productivity of dry mass and the formation of grain yield. In the present study, the LAI and total leaf dry mass were significantly increased with the supply of $\mathrm{N}$ and $\mathrm{K}$. Chlorophyll is one of the most important pigments in leaves, and it is capable of transforming sunlight into dry mass through photosynthesis (Xiong et al., 2015). Several studies have shown the high correlations between crop yields and leaf chlorophyll concentrations (Scharf et al., 2006; Anand and Byju, 2008; Rorie et al., 2011). Interestingly, the chlorophyll concentrations decreased with increasing $\mathrm{K}$ rates, while the grain yield increased with increasing $\mathrm{K}$ rates. What explains this phenomenon? Previous studies had shown that higher leaf mass was accompanied by lower leaf $\mathrm{N}$ concentration, which could be a dilution effect due to the leaf expansion and increasing carbon compounds (Bussotti et al., 2000; Mediavilla and Escudero, 2003). The results indicated that the increase of $\mathrm{K}$ rates significantly decreased the chlorophyll concentrations and chlorophyll accumulation (Figure 4 and Table 1), while 
increased the leaf area and dry mass (Table 1). Although the increase of $\mathrm{K}$ rates decreased the chlorophyll concentrations per leaf area of a single leaf, the total chlorophyll accumulation rates increased with the increase of $\mathrm{K}$ rates (Table 1). Thus, the decreased chlorophyll concentrations could be counterbalanced by the larger leaf area and dry mass, which in turn resulted in higher grain yield, as indicated by the significant positive relationships among grain yield, LAI, and leaf dry mass (Figure 10). The results indicated that the application of $\mathrm{N}$ and $\mathrm{K}$ could both significantly improve the total chlorophyll accumulation rates, and positively correlated with the grain yield (Figure 9).

In summary, the observed field phenomenon that the increase in $\mathrm{K}$ rates decreased leaf greenness but increased final grain yield can be explained as follows. The increased $\mathrm{K}$ rates decreased leaf $\mathrm{N}$ and $\mathrm{Mg}$ concentrations, which are two important nutrients in the synthesis of chlorophyll, and led to the decreases of chlorophyll concentrations and paler leaves. The more $\mathrm{K}$ was supplied, the paler the leaf became, especially under low $\mathrm{N}$ conditions. The increase of $\mathrm{K}$ rates also decreased leaf $\mathrm{N}$ and $\mathrm{Mg}$ concentrations under high $\mathrm{N}$ conditions. However, the differences in leaf greenness between different $\mathrm{K}$ rates could not be recognized by the naked eye under relatively high $\mathrm{N}$ rates compared with that under low $\mathrm{N}$ conditions. Furthermore, our data also indicate that SPAD readings cannot be used as reliable estimate of the relative grain yield because the highest SPAD readings not always resulted in the highest yield. The highest yield achieved with a combined use of $180 \mathrm{~N}$ and $180 \mathrm{~K} \mathrm{~kg} \mathrm{ha}^{-1}$, and further increase of $\mathrm{N}$ and SPAD readings did not increase the grain yield.

\section{CONCLUSIONS}

Contrary to the conventional understanding, at least at the jointing stage, rice leaf color was enhanced with the increase of $\mathrm{N}$ rates and decreased with the increase of $\mathrm{K}$ rates. However, the increased $\mathrm{K}$ rates decreased leaf greenness but increased grain yield. We proposed two hypotheses: (i) the increase of $\mathrm{K}$ rates decreased leaf $\mathrm{N}$ and $\mathrm{Mg}$ concentrations due to the antagonistic relationships between $\mathrm{K}^{+}$and $\mathrm{NH}_{4}^{+}$as well as $\mathrm{Mg}^{2+}$, or (ii) the increase of $\mathrm{K}$ rates promoted leaf development, which diluted the leaf $\mathrm{N}$ and $\mathrm{Mg}$ concentrations.

Based on the field observations and research data, our results clearly demonstrated the following conclusions. (1) The application of $\mathrm{K}$ in a $\mathrm{N}$ deficient soil will exacerbate the

\section{REFERENCES}

Anand, M. H., and Byju, G. (2008). Chlorophyll meter and leaf colour chart to estimate chlorophyll content, leaf colour, and yield of cassava. Photosynthetica 46, 511-516. doi: 10.1007/s11099-008-0087-8

Andrist-Rangel, Y., Edwards, A. C., Hillier, S., and Öborn, I. (2007). Long-term K dynamics in organic and conventional mixed cropping systems as related to management and soil properties. Agr. Ecosyst. Environ. 122, 413-426. doi: 10.1016/j.agee.2007.02.007

Arnon, D. I. (1949). Copper enzymes in isolated chloroplasts. Polyphenoloxidase in beta vulgaris. Plant Physiol. 24, 1-15. doi: 10.1104/pp.24.1.1 deficiency of leaf $\mathrm{N}$ and further decrease leaf greenness, which will overestimate the actual demand for $\mathrm{N}$ fertilizer in diagnosing rice $\mathrm{N}$ status and waste $\mathrm{N}$ fertilizer. (2) The increase of total leaf area and dry mass could counterbalance the negative effects of decreased leaf $\mathrm{N}$ and chlorophyll concentration for the supply of $\mathrm{K}$. The slight leaf greenness caused by the increase of $\mathrm{K}$ has no negative effects on grain yield, but will overstate the recommended $\mathrm{N}$ fertilizer in rice leaf $\mathrm{N}$ diagnosis. Based on this study, the application of $\mathrm{N}$ and $\mathrm{K}$ fertilizer in rice production systems should be balanced due to the antagonistic relationship between $\mathrm{K}^{+}$and $\mathrm{NH}_{4}{ }^{+}$, and $\mathrm{Mg}$ fertilizer should be considered due to the antagonistic relationships between $\mathrm{K}^{+}$and $\mathrm{Mg}^{2+}$.

\section{DATA AVAILABILITY STATEMENT}

The raw data supporting the conclusions of this article will be made available by the authors, without undue reservation, to any qualified researcher.

\section{AUTHOR CONTRIBUTIONS}

JL, RC, TR and XL conceived the idea and led the study design. $\mathrm{WH}$ performed experiments with support by JY and $\mathrm{SH}$. WH wrote the manuscript. MT and XL provided advice and edited the manuscript. All authors read and approved the final manuscript.

\section{FUNDING}

This work was supported by the National Key Research and Development Program of China (2016YFD0200108), the National Natural Science Foundation of China (31872174), the Special Fund for Agro-scientific Research in the Public Interest (No. 201503123), and the Fundamental Research Funds for the Central Universities (2662017JC010).

\section{ACKNOWLEDGMENTS}

We are grateful to the staff at the agricultural bureau of Wuxue City for their agricultural support.

Ata-Ul-Karim, S. T., Cao, Q., Zhu, Y., Tang, L., Rehmani, M. I. A., and Cao, W. X. (2016). Non-destructive assessment of plant nitrogen parameters using leaf chlorophyll measurements in rice. Front. Plant Sci. 7, 1-14. doi: 10.3389/fpls.2016.01829

Baligar, V. (2001). Nutrient management for improving lowland rice productivity and sustainability. Adv. Agron. 32, 2603-2629. doi: 10.1081/CSS-120000394

Berenguer, P., Santiveri, F., Boixadera, J., and Lloveras, J. (2009). Nitrogen fertilisation of irrigated maize under Mediterranean conditions. Eur. J. Agron. 30, 163-171. doi: 10.1016/j.eja.2008.09.005

Bussotti, F., Borghini, F., Celesti, C., Leonzio, C., and Bruschi, P. (2000). Leaf morphology and macronutrients in broadleaved trees in central Italy. Trees 14, 361-368. doi: 10.1007/s004680000056 
Castelli, F., Contillo, R., and Miceli, F. (1996). Non-destructive determination of leaf chlorophyll content in four crop species. J. Agron. Crop Sci. 177, 275-283. doi: 10.1111/j.1439-037x.1996.tb00246.x

Castillejo, M. A., Kirchev, H. K., and Jorrin, J. V. (2010). Differences in the triticale (X Triticosecale Wittmack) flag leaf 2-DE protein profile between varieties and nitrogen fertilization levels. J. Agr. Food Chem. 58, 5698-5707. doi: 10.1021/ jf100215t

Ceylan, Y., Kutman, U. B., Mengutay, M., and Cakmak, I. (2016). Magnesium applications to growth medium and foliage affect the starch distribution, increase the grain size and improve the seed germination in wheat. Plant Soil 406, 145-156. doi: 10.1007/s11104-016-2871-8

Chapagain, A. K., and Hoekstra, A. Y. (2011). The blue, green and grey water footprint of rice from production and consumption perspectives. Ecol. Econ. 70, 749-758. doi: 10.1016/j.ecolecon.2010.11.012

Collins, M., and Duke, S. H. (1981). Influence of potassium-fertilization rate and form on photosynthesis and $\mathrm{N}_{2}$ fixation of alfalfa. Crop Sci. 21, 481-485. doi: 10.2135/cropsci1981.0011183X002100040001x

Confalonieri, R., Paleari, L., Movedi, E., Pagani, V., Orlando, F., Foi, M., et al. (2015). Improving in vivo plant nitrogen content estimates from digital images: trueness and precision of a new approach as compared to other methods and commercial devices. Biosyst. Eng. 135, 21-30. doi: 10.1016/ j.biosystemseng.2015.04.013

Coskun, D., Britto, D. T., and Kronzucker, H. J. (2016). The nitrogen-potassium intersection: membranes, metabolism, and mechanism. Plant Cell Environ. 40, 2029-2041. doi: 10.1111/pce.12671

Erel, R., Yermiyahu, U., Ben-Gal, A., Dag, A., Shapira, O., and Schwartz, A. (2015). Modification of non-stomatal limitation and photoprotection due to $\mathrm{K}$ and $\mathrm{Na}$ nutrition of olive trees. J. Plant Physiol. 177, 1-10. doi: 10.1016/ j.jplph.2015.01.005

Gandin, A., Lapointe, L., and Dizengremel, P. (2009). The alternative respiratory path way allows sink to cope with changes in carbon availability in the sinklimited plant Erythronium americanum. J. Exp. Bot. 60, 4235-4248. doi: $10.1093 /$ jxb/erp255

Gerardeaux, E., Jordan-Meille, L., and Pellerin, S. (2009). Radiation interception and con-version to biomass in two potassium-deficient cotton crops in South Benin. J. Agric. Sci. 147, 155-168. doi: 10.1017/s0021859608008381

Gu, J. F., Zhou, Z. X., Li, Z. K., Chen, Y., Wang, Z. Q., and Zhang, H. (2017). Rice (Oryza sativa, L.) with reduced chlorophyll content exhibit higher photosynthetic rate and efficiency, improved canopy light distribution, and greater yields than normally pigmented plants. Field Crop Res. 200, 58-70. doi: 10.1016/j.fcr.2016.10.008

Guo, J. H., Liu, X. J., Zhang, Y., Shen, J. L., Han, W. X., Zhang, W. F., et al. (2010). Significant acidification in major Chinese croplands. Science 327, 1008-1010. doi: 10.1126/science. 1182570

Hall, J. D., Barr, R., Al-Abbas, A. H., and Crane, F. L. (1972). The ultrastructure of chloroplasts in mineral-deficient maize leaves. Plant Physiol. 50, 404-409. doi: $10.1104 / p p .50 .3 .404$

Hoa, N. M., Janssen, B. H., Oenema, O., and Dobermann, A. (2006). Comparison of partial and complete soil $\mathrm{K}$ budgets under intensive rice cropping in the Mekong Delta, Vietnam. Agr. Ecosyst. Environ. 116, 121-131. doi: 10.1016/ j.agee.2006.03.020

Hou, W. F., Yan, J. Y., Jákli, B., Lu, J. W., Cong, R. H., and Li, X. K. (2018). Synergistic effects of nitrogen and potassium on quantitative limitations to photosynthesis in rice (Oryza sativa L.). J. Agr. Food Chem. 66, 5125-5132. doi: 10.1021/acs.jafc.8b01135

Hu, W., Yang, J. S., Meng, Y. L., Wang, Y. H., Chen, B. L., Zhao, W. Q., et al. (2015). Potassium application affects carbohydrate metabolism in the leaf subtending the cotton (Gossypium hirsutum L.) boll and its relationship with boll biomass. Field Crop Res. 179, 120-131. doi: 10.1016/j.fcr.2015.04.017

Hu, W., Jiang, N., Yang, J. S., Meng, Y. L., Wang, Y. H., Chen, B. L., et al. (2016). Potassium (K) supply affects K accumulation and photosynthetic physiology in two cotton (Gossy pium hirsutum L.) cultivars with different $\mathrm{K}$ sensitivities. Field Crop Res. 196, 51-63. doi: 10.1016/j.fcr.2016.06.005

Hu, W., Coomer, T. D., Loka, D. A., Oosterhuis, D. M., and Zhou, Z. G. (2017). Potassium deficiency affects the carbon-nitrogen balance in cotton leaves. Plant Physiol. Bioch. 115, 408-417. doi: 10.1016/j.plaphy.2017.04.005
Huang, J. L., He, F., Cui, K. H., Buresh, R. J., Xu, B., Gong, W. H., et al. (2008). Determination of optimal nitrogen rate for rice varieties using a chlorophyll meter. Field Crops Res. 105, 70-80. doi: 10.1016/j.fcr.2007.07.006

Jákli, B., Tavakol, E., Tränkner, M., Senbayram, M., and Ditter, K. (2016). Quantitative limitations to photosynthesis in $\mathrm{K}$ deficient sunflower and their implications on water-use efficiency. J. Plant Physiol. 209, 20-30. doi: 10.1016/ j.jplph.2016.11.010

Jia, Y. B., Yang, X. E., Islam, E., and Feng, Y. (2008). Effects of potassium deficiency on chloroplast ultrastructure and chlorophyll fluorescence in inefficient and efficient genotypes of rice. J. Plant Nutr. 31, 2105-2118. doi: 10.1080/ 01904160802459625

Jiang, P., Xie, X. B., Huang, M., Zhou, X. F., Zhang, R. C., Chen, J. N., et al. (2016). Potential yield increase of hybrid rice at five locations in southern China. Rice 9, 1-14. doi: 10.1186/s12284-016-0085-6

Kaufman, R. C., Wilson, J. D., Bean, S. R., Presley, D. R., Blanco-Canqui, H., and Mikha, M. (2013). Effect of nitrogen fertilization and cover cropping systems on sorghum grain characteristics. J. Agr. Food Chem. 61, 5715-5719. doi: $10.1021 /$ jf401179n

Khurana, H. S., Phillips, S. B., Singh, B., Dobermann, A., Sidhu, A. S., Singh, Y., et al. (2007). Performance of site-specific nutrient management for irrigated, transplanted rice in northwest India. Agron. J. 99, 1436-1447. doi: 10.2134/ agronj2006.0283

Kusano, M., Fukushima, A., Redestig, H., and Saito, K. (2011). Metabolomic approaches toward understanding nitrogen metabolism in plants. J. Exp. Bot. 62, 1439-1453. doi: 10.1093/jxb/erq417

Lavres, J. J., and Monteiro, F. A. (2010). Nitrate reductase activity and spad readings in leaf tissues of guinea grass submitted to nitrogen and potassium rates. Rev. Bras. Cienc. Solo 34, 801-809. doi: 10.1590/S010006832010000300022

Laza, R. C., Bergman, B., and Vergara, B. S. (1993). Cultivar differences in growth and chloroplast ultrastructure in rice as affected by nitrogen. J. Exp. Bot. 44, 1643-1648. doi: 10.1093/jxb/44.11.1643

Li, J. W., Yang, J. P., Fei, P. P., Song, J. L., Li, D. S., Ge, C. S., et al. (2009). Responses of rice leaf thickness, SPAD readings and chlorophyll $\mathrm{a} / \mathrm{b}$ ratios to different nitrogen supply rates in paddy field. Field Crop Res. 114, 426-432. doi: 10.1016/ j.fcr.2009.09.009

Li, Y., Ren, B. B., Ding, L., Shen, Q. R., Peng, S. B., and Guo, S. W. (2013). Does chloroplast size influence photosynthetic nitrogen use efficiency? PloS One 8, 1-10. doi: 10.1371/journal.pone.0062036

Liu, X. J., Zhang, K., Zhang, A. Y., Cao, Q., Lv, A. F., Yuan, Z. F., et al. (2017). Canopy chlorophyll density based index for estimating nitrogen status and predicting grain yield in rice. Front. Plant Sci. 8, 1829. doi: 10.3389/ fpls.2017.01829

Long, S. P. (2012). Virtual Special Issue (VSI) on mechanisms of plant response to global atmospheric change. Plant Cell Environ. 35, 1705-1706. doi: 10.1111/ j.1365-3040.2012.02589.x

Luo, Y. L., Tang, Y. H., Zhang, X., Li, W. Q., Chang, Y. L., Pang, D. W., et al. (2018). Interactions between cytokinin and nitrogen contribute to grain mass in wheat cultivars by regulating the flag leaf senescence process. Crop J. 6, 538551. doi: 10.1016/j.cj.2018.05.008

Makino, A. (2011). Photosynthesis, grain yield, and nitrogen utilization in rice and wheat. Plant Physiol. 155, 125-129. doi: 10.1104/pp.110.165076

Mediavilla, S., and Escudero, A. (2003). Relative growth rate of leaf biomass and leaf nitrogen content in several mediterranean woody species. Plant Ecol. 168, 321-332. doi: 10.1023/a:1024496717918

Neuhaus, C., Geilfus, C. M., Zörb, C., and Mühling, K. H. (2013). Transcript expression of $\mathrm{Mg}$-chelatase and $\mathrm{H}^{+}$-ATPase isogenes in Viciafaba leaves as influenced by root and foliar magnesium supply. Plant Soil 368, 41-50. doi: 10.1007/s11104-013-1711-3

Oosterhuis, D. M., Loka, D. A., Kawakami, E. M., and Pettigrew, W. T. (2014). Chapter Three-the physiology of potassium in crop production. Adv. Agron. 126, 203-233. doi: 10.1016/B978-0-12-800132-5.00003-1

Peng, S. B., García, F. V., Laza, R. C., and Cassman, K. G. (1993). Adjustment for specific leaf weight improves chlorophyll meter's estimate of rice leaf nitrogen concentration. Agron. J. 85, 987-990. doi: 10.2134/agronj1993. $00021962008500050005 \mathrm{x}$ 
Pettigrew, W. T. (2008). Potassium influences on yield and quality production for maize, wheat, soybean and cotton. Physiol. Plant. 133, 670-681. doi: 10.1111/ j.1399-3054.2008.01073.x

Pradhan, S., Patra, P., Mitra, S., Dey, K. K., Jain, S., Sarkar, S., et al. (2014). Manganese nanoparticles: impact on non-nodulated plant as a potent enhancer in nitrogen metabolism and toxicity study both in vivo and in vitro. J. Agr. Food Chem. 62, 8777-8785. doi: 10.1021/jf502716c

Qiao, J., Yang, L. Z., Yan, T. M., Xue, F., and Zhao, D. (2012). Nitrogen fertilizer reduction in rice production for two consecutive years in the Taihu Lake area. Agr. Ecosyst. Environ. 146, 103-112. doi: 10.1016/j.agee.2011.10.014

Qiu, S. J., Xie, J. G., Zhao, S. C., Xu, X. P., Hou, Y. P., Wang, X. F., et al. (2014). Long-term effects of potassium fertilization on yield, efficiency, and soil fertility status in a rain-fed maize system in northeast China. Field Crops Res. 163, 1-9. doi: 10.1016/j.fcr.2014.04.016

Rorie, R. L., Purcell, L. C., Mozaffari, M., Karcher, D. E., King, C. A., Marsh, M. C., et al. (2011). Association of "greenness" in corn with yield and leaf nitrogen concentration. Agron. J. 103, 529-535. doi: 10.2134/agronj2010.0296

Rotbart, N., Schmilovitch, Z., Cohen, Y., Alchanatis, V., Erel, R., Ignat, T., et al. (2013). Estimating olive leaf nitrogen concentration using visible and?nearinfrared spectral reflectance. Biosyst. Eng. 114, 426-434. doi: 10.1016/ j.biosystemseng.2012.09.005

Scharf, P. C., Brouder, S. M., and Hoeft, R. G. (2006). Chlorophyll meter readings can predict nitrogen need and yield response of corn in the north-central USA. Agron. J. 98, 655-665. doi: 10.2134/agronj2005.0070

Sims, D. A., Seemann, J. R., and Luo, Y. Q. (1998). Elevated $\mathrm{CO}_{2}$ concentration has independent effects on expansion rates and thickness of soybean leaves across light and nitrogen gradients. J. Exp. Bot. 49, 583-591. doi: 10.1093/jxb/49.320.583

Singh, B., Singh, Y., Ladha, J. K., Bronson, K. F., Balasubramanian, V., Singh, J., et al. (2002). Chlorophyll meter-and leaf color chart-based nitrogen management for rice and wheat in northwestern India. Agron. J. 94, 821829. doi: 10.2134/agronj2002.0821

Thomas, R. L., Sheard, R. W., and Moyer, J. R. (1967). Comparison of conventional and automated procedures for nitrogen, phosphorus, and potassium analysis of plant material using a single digestion. Agron. J. 59, 240-243. doi: 10.2134/agronj1967.00021962005900030010x

Timsina, J., Singh, V. K., and Majumdar, K. (2013). Potassium management in rice-maize systems in south Asia. J. Plant Nutr. Soil Sc. 000, 1-14. doi: 10.1002/jpln.201200253

Tränkner, M., Tavakol, E., and Jákli, B. (2018). Functioning of potassium and magnesium in photosynthesis, photosynthate translocation and photoprotection. Physiol. Plant. 163, 414-431. doi: 10.1111/ppl.12747

Wang, F. M., Huang, J. F., Tang, Y. L., and Wang, X. Z. (2007). New vegetation index and its application in estimating leaf area index of rice. Rice Sci. 14, 195203. doi: $10.1016 / \mathrm{s} 1672-6308(07) 60027-4$

Wang, N., Hua, H., Egrinya Eneji, A., Li, Z., Duan, L., and Tian, X. (2012). Genotypic varia-tions in photosynthetic and physiological adjustment to potassium deficiencyin cotton (Gossypium hirsutum). J. Photochem. Photobiol. B: Biol. 110, 1-8. doi: 10.1016/j.jphotobiol.2012.02.002

Wang, Y., Wang, D. J., Shi, P. H., and Omasa, K. (2014). Estimating rice chlorophyll content and leaf nitrogen concentration with a digital still color camera under natural light. Plant Methods 10, 1-11. doi: 10.1186/1746-4811-10-36
Xiong, D. L., Chen, J., Yu, T. T., Gao, W. L., Ling, X. X., Li, Y., et al. (2015). SPADbased leaf nitrogen estimation is impacted by environmental factors and crop leaf characteristics. Sci. Rep. 5, 1-12. doi: 10.1038/srep13389

Xiong, D. L., Wang, D., Liu, X., Peng, S. B., Huang, J. L., and Li, Y. (2016). Leaf density explains variation in leaf mass per area in rice between cultivars and nitrogen treatments. Ann. Bot. 117, 963-971. doi: 10.1093/aob/mcw022

Yuan, Z. F., Cao, Q., Zhang, K., Ata-Ul-Karim, S. T., Tian, Y. C., Zhu, Y., et al. (2016). Optimal leaf positions for SPAD meter measurement in rice. Front. Plant Sci. 7, 1-10. doi: 10.3389/fpls.2016.00719

Zörb, C., Senbayram, M., and Peiter, E. (2014). Potassium in agriculture-status and perspectives. J. Plant Physiol. 171, 656-669. doi: 10.1016/j.jplph. 2013.08.008

Zhang, Y. L., Fan, J. B., Wang, D. S., and Shen, Q. R. (2009). Genotypic differences in grain yield and physiological nitrogen use efficiency among rice cultivars. Pedosphere 19, 681-691. doi: 10.1016/s1002-0160(09)60163-6

Zhang, F. S., Niu, J. F., Zhang, W. F., Chen, X. P., Li, C. J., Yuan, L. X., et al. (2010). Potassium nutrition of crops under varied regimes of nitrogen supply. Plant Soil 335, 21-34. doi: 10.1007/s11104-010-0323-4

Zhang, Y., Zhang, C. C., Yan, P., Chen, X. P., Yang, J. C., Zhang, F. S., et al. (2013). Potassium requirement in relation to grain yield and genotypic improvement of irrigated lowland rice in China. J. Plant Nutr. Soil Sc. 176, 400-406. doi: 10.1002/jpln.201200206

Zhang, W. J., Wu, L. M., Wu, X. R., Ding, Y. F., Li, G. H., Li, J. Y., et al. (2016). Lodging resistance of japonica rice (Oryza Sativa L.): morphological and anatomical traits due to top-dressing nitrogen application rates. Rice 9, 1-11. doi: 10.1186/s12284-016-0103-8

Zhao, D. L., Oosterhuis, D. M., and Bednarz, C. W. (2001). Influence of potassium deficiency on photosynthesis, chlorophyll content, and chloroplast ultrastructure of cotton plants. Photosynthetica 39, 103-109. doi: 10.1023/ a: 1012404204910

Zhao, D. L., Reddy, K. R., Kakani, V. G., and Reddy, V. R. (2005). Nitrogen deficiency effects on plant growth, leaf photosynthesis, and hyperspectral reflectance properties of sorghum. Eur. J. Agron. 22, 391-403. doi: 10.1016/ j.eja.2004.06.005

Zhu, Y., Yao, X., Tian, Y. C., Liu, X. J., and Cao, W. X. (2008). Analysis of common canopy vegetation indices for indicating leaf nitrogen accumulations in wheat and rice. Int. J. Appl. Earth Obs. 10, 1-10. doi: 10.1016/j.jag. 2007.02 .006

Conflict of Interest: The authors declare that the research was conducted in the absence of any commercial or financial relationships that could be construed as a potential conflict of interest.

Copyright (๑) 2020 Hou, Tränkner, Lu, Yan, Huang, Ren, Cong and Li. This is an open-access article distributed under the terms of the Creative Commons Attribution License (CC BY). The use, distribution or reproduction in other forums is permitted, provided the original author(s) and the copyright owner(s) are credited and that the original publication in this journal is cited, in accordance with accepted academic practice. No use, distribution or reproduction is permitted which does not comply with these terms. 